\title{
Definitions and Analyses of Components of Stand Increments
}

\section{SEREF ALEMDAG}

Forest Management Institute, Canadian Forestry Service,

Ottawa, Ontario

$\mathrm{K} 1 \mathrm{~A} \mathrm{OH} 3$

\begin{abstract}
Although the terms used in forestry to describe various forms of increment and mortality are fairly well established by usage, confusion is still encountered in their use. This paper analyzes and clarifies these terms which refer to stand development, and illustrates them with examples for use, trial, criticism and refinement toward possible future standardization.
\end{abstract}

\section{Introduction}

Increment, as defined by the Terminology of Forest Science, Technology, Practice and Products (Ford-Robertson 1971), is "the increase in girth, diameter, basal area, height, volume, quality or value of individual trees or crops". More specifically, for example, increment of a tree in terms of volume is the difference between two successive volumes obtained by two successive tree measurements with respect to changes in dimensions. This case however is not so simple when applied to a stand of trees. Here it is complicated because, within the growing period bounded by two measurements, other changes take place as well. Some trees may die, be cut, or grow into measurable sizes. Although the terms used in describing various forms of increment and mortality are fairly well established through the years of practice in forestry, there still is some confusion encountered in their use. The intention of this paper is to analyze and clarify these terms when used in conjunction with a stand's development, and to illustrate them with examples for use, trial, criticism and refinement toward possible future standardization. For simplicity, the discussion is confined to only one increment characteristic, volume, in cubic measure. The symbols are chosen, and expressed in capital letters so that they may be readily used with a computer.

The terms growth and increment are often used synonymously. However growth has many implications with no widely accepted definitions, and in European usage commonly expresses the accumulated value of any growth element attained by a tree or stand at a particular time, e.g. total height. Therefore, the use of the term growth to express increment is purposely avoided in this paper. The term increment is used to describe the physical enlargement of a tree or stand in a specific period.
The components of stand increments defined and explained herein apply to the general or ideal case where all of the elements of change, i.e., initial volume, final volume, ingrowth, cut and mortality are measured directly, such as on permanent sample plots. Where all elements are not measured directly as in single-examination sample plots using increment cores, or on permanent sample plots with only initial and final volumes measured, the reliability and methods of calculating the components are quite different, although the terminology is similar. Problems associated with these partial measurements of increment components are not dealt with in this paper.

\section{Basic terminology}

The terminology employed in this paper is generally consistent with that found in the attached bibliography, although the authors concerned differ somewhat amongst themselves. To avoid ambiguity, definitions given later based on the following usage:

The terms net and gross do not refer to soundness or defect. Herein, total volume is always implied, irrespective of the amount of cull; net refers to increment excluding mortality, whereas gross increment includes mortality.

Growing period is the time between two successive measurements - usually expressed in years, representing numbers of full growing seasons, but fractional values may be used if successive measurements are made at different times within each growing season.

Ingrowth comprises trees which, below the minimum diameter at the beginning of the growing period, grew into measurable size during it.

Accretion refers to the volume added, by enlargement of the individual trees, to the stand present at the beginning of the growing period (on a single tree, however, this is the volume added to the initial volume of the tree as a result of dimensional enlargements by the end of the growing period).

\section{Definitions of terms for computing increment}

For analyzing and calculating increment, it is simplest to deal separately with the two elements making up the stand, and then to deal with their combined behaviour. By following this order, the definitions of the increment terms are given 
below in more detail. In these terms initial means at the time of the measurement at the beginning of the period, and present means at the time of the measurement at the end of the period. Where:

I. The first element comprises those trees recorded at the initial measurement:

Initial volume of original stand (IVO) $=$ beginning-of-period volume of living trees above a given diameter present at the beginning of the period;

Present volume of original stand $(\mathrm{PVO})=$ end-of-period volume of trees which were present at the beginning of the period but may or may not be present at the end of the period $=$ volume of living trees remaining from original stand plus volume of cut from original stand plus volume of mortality from original stand, all at the end of the period;

Present volume of cut from original stand (PVCO) $=$ end-of-period volume of that part of the original stand harvested from living trees during the period, whether removed from the forest or not $=$ initial volume of cut from original stand (IVCO) plus its accretion;

Present volume of mortality from original stand $(P V M O)=$ end-of-period volume of that part of the original stand which died during the period, whether salvaged or not $=$ initial volume of mortality from original stand (IVMO) plus its accretion;

Initial volume of living trees remaining from original stand (IVRO) = beginning-of-period volume of original stand alive at the end of the period;

Present volume of living trees remaining from original stand (PVRO) = end-of-period volume of original stand alive at the end of the period;

Volume of accretion (ACC) = volume added to the volume of original stand, including those parts which were harvested or died, during the period $=$ present volume of original stand minus initial volume of original stand;

II. The second element is ingrowth:

Present volume of cut ingrowth (PVCI) $=$ end-of-period volume of ingrowth harvested during the period, whether removed from the forest or not;

Present volume of dead ingrowth (PVMI) $=$ end-of-period volume of ingrowth which died during the period, whether salvaged or not;

Present volume of living ingrowth (PVLI) $=$ end-of-period volume of ingrowth alive at the end of the period;

Present volume of ingrowth $(\mathrm{PVI})=$ end-ofperiod volume of ingrowth comprising living, dead and cut;

III. The combined elements result in overall stand change:

Present volume of present stand (PVP) $=$ volume present at the end of the period $=$ end-ofperiod volume of original stand alive at the end of the period plus end-of-period volume of living ingrowth;

Initial volume of present stand (IVP) = beginning-of-period volume of present stand = initial volume of living trees remaining from original stand plus initial volume of living ingrowth (IVLI) which is zero $=$ initial volume of living trees remaining from original stand;

Present volume of cut (PVC) $=$ present volume of cut from original stand plus present of cut ingrowth;

Present volume of mortality $(\mathrm{PVM})=$ present volume of mortality from original stand plus present volume of dead ingrowth;

Volume of depletion (DEP) $=$ volume deducted from the sum of the volumes of both original stand and ingrowth within the period $=$ cut plus mortality;

Net increase or net change $(\mathrm{NC})=$ present volume of present stand minus initial volume of original stand $=$ present volume of living trees remaining from original stand plus present volume of living ingrowth minus initial volume of original stand;

Survivor increment of original stand $(\mathrm{SIO})=$ volume added to the initial volume of surviving trees of original stand $=$ present volume of living trees remaining from original stand minus initial volume of living trees remaining from original stand;

Survivor increment of ingrowth (SII) = volume added to the initial volume of surviving trees of ingrowth $=$ present volume of living ingrowth;

Survivor increment (SUI) = survivor increment of original stand plus survivor increment of ingrowth;

Net increment $(\mathrm{NI})=$ volume of accretion plus present volume of ingrowth minus present volume of mortality $=$ gross increment minus present volume of mortality $=$ net increase plus present volume of cut;

Gross increment (GI) = volume of accretion plus present volume of ingrowth $=$ net increase plus present volume of cut plus present volume of mortality $=$ net increment plus present volume of mortality;

Periodic increment $(\mathrm{PI})=$ total increment for a period of $n$ years; net or gross;

Current annual increment (CAI) $=$ increment for a specific year, or yearly increment; net or gross (On a single tree this is the difference between the volumes at the beginning and at the end of a year's growth, and can only be net);

Periodic annual increment $(\mathrm{PAI})=$ average annual increment over a period of $n$ years which is often used in place of CAI because of the usually greater ease and greater certainty of its calculation; net or gross $=$ total increment for a period of $n$ years divided by $n$ years;

Mean annual increment $(\mathrm{MAl})=$ average annual increment to any age; actual, accumulated net or accumulated gross $=$ cumulative volume divided by the number of years required to produce it. The terms (a) actual, (b) accumulated net and (c) accumulated gross imply, respectively, the mean annual increment calculated (a) for the present volume, (b) for the present volume plus 
accumulated cut, and (c) for the present volume plus accumulated cut plus accumulated mortality, of a stand at a given age.

In regard to the above descriptions, the following three points have to be remembered:

1. Except in special cases, if a tree is cut in a known year within the growing period, and even if its dimensions are measured at that particular time, it is assumed to have been cut at the end of the growing period, but to have had the size observed at the time of cut, or, if this size were not available, at the time of initial measurement. The volume of cut in a stand also includes the volume of trees that became ingrowth and then were cut, and accretion of the cut trees which occurred between the beginning of the growing period and the time of cut. These concepts are also true for dead trees. In exceptional cases, such as intensive studies where cut and death are observed closely within the growing period, a different approach is required, i.e., calculations may be carried out considering the year of cut or death and the tree size in that particular year.

2. Ingrowth is always measured and included in the observed data at the second measurement, either by recording ingrowth without distinction with the initially measured living trees; or separately, by marking all the measured living trees at the time of establishment of the observation area. This matter has to be considered in the calculations if ingrowth is to be excluded from the increment values.

3. Increment, cut, mortality and ingrowth determined for a growing period, belongs to the stand at the beginning of the period and reflects the development of this stand from its initial stage to its present stage.

\section{Calculations}

Before formulating the calculations of the increment values, it will be worthwhile to summarize the essential relationships as follows:

PVI = PVCI + PVMI + PVLI
PVC $=$ PVCO + PVCI
PVM = PVMO + PVMI
PVP = PVRO + PVLI
ACC = (PVRO + PVCO + PVMO - IVO
NC = PVP - IVO
SIO = PVRO - IVRO
NI $=$ GI - PVM
GI $=$ ACC + PVI

When calculating the increment values for a period of $n$ years, i.e., after having two sets of observed data taken at two dates from the same area by the same standards, it may be desirable not to include ingrowth. The two cases, one where ingrowth is included, and one where it is not, are presented as follows:

(a) If increment includes ingrowth, then -

$$
\begin{aligned}
\mathrm{PVM}= & \mathrm{PVMO}+\mathrm{PVMI} \\
\mathrm{ACC}= & (\mathrm{PVRO}+\mathrm{PVCO}+\mathrm{PVMO})-\mathrm{IVO} \\
= & (\mathrm{PVP}-\mathrm{PVLI})+(\mathrm{PVCO}+
\end{aligned}
$$

$$
\begin{aligned}
& \text { PVMO })- \text { IVO }=(\text { PVP }- \text { IVO })+ \\
& (\mathrm{PVC}+\mathrm{PVM})-\mathrm{PVI} \\
& \mathrm{NC}=\mathrm{PVRO}+\mathrm{PVLI}-\mathrm{IVO}=\mathrm{PVP}- \\
& \text { IVO } \\
& \mathrm{SUI}=(\mathrm{PVRO}-\mathrm{IVRO})+\mathrm{PVLI}=(\mathrm{PVP} \\
& - \text { PVLI }- \text { IVRO) }+ \text { PVLI }=\text { PVP } \\
& \text { - IVRO } \\
& \mathrm{NI}=[(\mathrm{PVP}-\mathrm{IVO})+(\mathrm{PVC}+\mathrm{PVM}) \\
& -\mathrm{PVI}]+\mathrm{PVI}-\mathrm{PVM}=(\mathrm{PVP}- \\
& \text { IVO) + PVC } \\
& \mathrm{GI}=[(\mathrm{PVP}-\mathrm{IVO})+(\mathrm{PVC}+\mathrm{PVM})- \\
& \mathrm{PVI}]+\mathrm{PVI}=(\mathrm{PVP}-\mathrm{IVO})+ \\
& (\mathrm{PVC}+\mathrm{PVM})
\end{aligned}
$$

PAI net $=\mathrm{NI}$ including ingrowth $/ n$ years

PAI gross $=\mathrm{GI}$ including ingrowth $/ n$ years

MAI actual $=$ PVP/age in years;

(b) If increment does not include ingrowth, then -

$$
\begin{aligned}
& \mathrm{PVM}=\mathrm{PVMO} \\
& \mathrm{ACC}=(\mathrm{PVP}-\mathrm{IVO})+(\mathrm{PVC}+\mathrm{PVM}) \\
& -\mathrm{PVI}=(\mathrm{PVP}-\mathrm{PVLI})+(\mathrm{PVCO} \\
& + \text { PVMO })- \text { IVO }=(\text { PVRO }+ \\
& \text { PVCO + PVMO) - IVO } \\
& \mathrm{NC}=\mathrm{PVP}-\mathrm{IVO}-\mathrm{PVLI}=\mathrm{PVRO} \\
& \text { - IVO } \\
& \mathrm{SIO}=\text { PVRO }- \text { IVRO } \\
& \mathrm{NI}=[(\mathrm{PVP}-\mathrm{IVO})+(\mathrm{PVC}+\mathrm{PVM}) \\
& -\mathrm{PVI}]-\mathrm{PVMO}=(\mathrm{PVP}-\mathrm{IVO}) \\
& +(\mathrm{PVCO}+\mathrm{PVMO}-\mathrm{PVLI})- \\
& \mathrm{PVMO}=(\mathrm{PVRO}-\mathrm{IVO})+\mathrm{PVCO} \\
& \mathrm{GI}=(\mathrm{PVP}-\mathrm{IVO})+(\mathrm{PVC}+\mathrm{PVM}) \\
& -\mathrm{PVI}=(\mathrm{PVP}-\mathrm{PVLI}+\mathrm{PVCO} \\
& + \text { PVMO })- \text { IVO }=(\text { PVRO }+ \\
& \text { PVCO + PVMO) - IVO }
\end{aligned}
$$

PAI net $=$ NI excluding ingrowth $/ n$ years

PAI gross $=\mathrm{GI}$ excluding ingrowth $/ n$ years

MAI actual $=($ PVP - PVLI $) /$ age in years.

In case (b), net increase NC may be called net increase of initial volume of original stand, net increment $\mathrm{NI}$ may be called net increment of initial volume of original stand, and gross increment GI may be called gross increment of initial volume of original stand. In this case, accretion and gross increment are identical.

In both cases, net increase and net increment could have positive or negative values but survivor increment of original stand, gross increment and accretion are always positive. Also, accretion is the same in both cases, as is survivor increment of original stand.

It should be noted that the last forms of each of the above expressions are the simplest and most commonly used. Also, that the final results are expressed in terms of the present volume PVP in the first group, but of the present remaining volume PVRO in the second. These formulas can of course be manipulated in standard fashion by the subscription of equivalent terms when necessary.

The numerical example provided below indicates the method of calculating increments. The case has been simplified by the following assumptions:

1. Data are collected from a stand at two dates, 10 years apart.

2. The age of the stand at the beginning of the period is 115 years. 
Table 1. Distribution of tallied cut, dead and living trees, by diameter classes, on the observation area

\begin{tabular}{|c|c|c|c|c|c|c|c|c|c|c|c|c|c|c|}
\hline \multirow[b]{2}{*}{ Tree status } & & & \multicolumn{12}{|c|}{ Diameter class $-\mathbf{c m}$} \\
\hline & & & Ingrowth $=20 \mathrm{~cm}$ & 20 & 21 & 22 & 23 & 35 & 37 & 42 & 43 & 44 & 45 & Total \\
\hline Living at the beginning of the growing period & : & $\begin{array}{l}\text { NT } \\
\text { IVO }\end{array}$ & & $\begin{array}{l}120 \\
30.9\end{array}$ & $\begin{array}{l}90 \\
25.9\end{array}$ & & & $\begin{array}{l}80 \\
85.1\end{array}$ & & $\begin{array}{l}50 \\
82.0\end{array}$ & $\begin{array}{l}40 \\
69.2\end{array}$ & & & $\begin{array}{l}380 \\
293.1\end{array}$ \\
\hline Ingrowth & . & NT & $\begin{array}{l}40 \\
10.3\end{array}$ & & & & & & & & & & & $\begin{array}{l}290.1 \\
40 \\
10,3\end{array}$ \\
\hline Living just before cutting and dying & $\vdots$ & NT & 40 & & & 120 & 90 & & 80 & & & 50 & 40 & $\begin{array}{l}10.3 \\
420\end{array}$ \\
\hline Cut from the original & $\vdots$ & $\mathrm{VT}$ & 10.3 & & & 38.7 & 32.3 & & 97.1 & & & 91.2 & 76.7 & 346.3 \\
\hline Cut from the original & $\vdots$ & $\begin{array}{l}\text { NT } \\
\text { PVCO }\end{array}$ & & & & 3.2 & 1.8 & & 24.3 & & & 5.5 & & 34.8 \\
\hline Cut ingrowth & $\vdots$ & $\begin{array}{r}\text { NT } \\
\text { PVCI }\end{array}$ & $\begin{array}{l}4 \\
1.0\end{array}$ & & & & & & & & & & & $\begin{array}{l}4 \\
10\end{array}$ \\
\hline Total cut & : & NT & 4.0 & & & 10 & 5 & & 20 & & & 3 & & 42.0 \\
\hline Dead from the original & $\vdots$ & NT & 1.0 & & & $\begin{array}{l}3.2 \\
8\end{array}$ & & & & & & & 2 & $\begin{array}{l}35.8 \\
10\end{array}$ \\
\hline Dead ingrowth & $\vdots$ & PVMO & 19 & & & 2.6 & & & & & & & 3.8 & $\begin{array}{r}6.4 \\
19\end{array}$ \\
\hline Total dead & $\vdots$ & $\begin{array}{l}\text { PVMI } \\
\text { NT }\end{array}$ & $\begin{array}{r}4.9 \\
19\end{array}$ & & & 8 & & & & & & & 2 & $\begin{array}{l}4.9 \\
29\end{array}$ \\
\hline & $\vdots$ & PVM & 4.9 & & & 2.6 & & & & & & & 3.8 & 11.3 \\
\hline $\begin{array}{l}\text { Remaining from the original } \\
\text { (a) at the end of the growing period }\end{array}$ & $\vdots$ & $\begin{array}{r}\text { NT } \\
\text { PVRO }\end{array}$ & & & & $\begin{array}{c}102 \\
32.9\end{array}$ & $\begin{array}{l}85 \\
30.5\end{array}$ & & $\begin{array}{l}60 \\
72.8\end{array}$ & & & $\begin{array}{l}47 \\
85.7\end{array}$ & $\begin{array}{l}38 \\
72.9\end{array}$ & $\begin{array}{l}332 \\
294.8\end{array}$ \\
\hline (b) at the beginning of the growing period & $\vdots$ & $\begin{array}{r}\text { NT } \\
\text { IVRO }\end{array}$ & & $\begin{array}{l}102 \\
26.3\end{array}$ & $\begin{array}{l}85 \\
24.5\end{array}$ & & & $\begin{array}{l}60 \\
63.8\end{array}$ & & $\begin{array}{l}47 \\
77.1\end{array}$ & $\begin{array}{l}38 \\
65.8\end{array}$ & & & $\begin{array}{l}332 \\
257.5\end{array}$ \\
\hline Living ingrowth & $\vdots$ & $\begin{array}{r}\text { NT } \\
\text { PVLI }\end{array}$ & $\begin{array}{l}17 \\
4.4\end{array}$ & & & & & & & & & & & $\begin{array}{c}17 \\
4.4\end{array}$ \\
\hline Living at the end of the growing period & $\vdots$ & $\begin{array}{r}\text { NT } \\
\text { PVP }\end{array}$ & $\begin{array}{l}4.4 \\
17 \\
4.4\end{array}$ & & & $\begin{array}{c}102 \\
32.9\end{array}$ & $\begin{array}{l}85 \\
30.5\end{array}$ & & $\begin{array}{l}60 \\
72.8\end{array}$ & & & $\begin{array}{l}47 \\
85.7\end{array}$ & $\begin{array}{l}38 \\
72.9\end{array}$ & $\begin{array}{l}349 \\
299.2\end{array}$ \\
\hline
\end{tabular}

Figures in italics indicate number of trees (NT), and others indicate cubic metre volume, on 0.8 hectare. 
Table 2. Calculated increment values with ingrowth included and excluded

\begin{tabular}{lc|c}
\hline Type of increment & $\begin{array}{c}\text { For the growing period, } \\
\text { on the total area, } \mathrm{m}^{3}\end{array}$ & $\begin{array}{c}\text { Annual, on the } \\
\text { total area, } \mathrm{m}^{3}\end{array} \mathbf{A n n u a l , ~ p e r}^{\mathrm{hectare}, \mathrm{m}^{3}}$ \\
\hline
\end{tabular}

(a) Increment including ingrowth

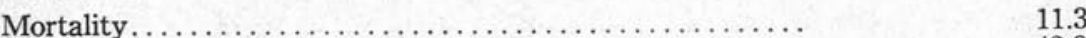

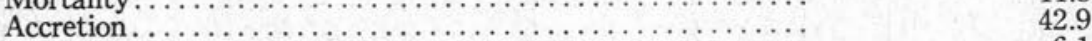

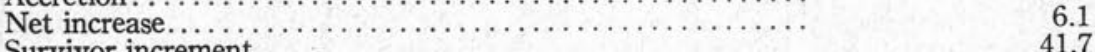

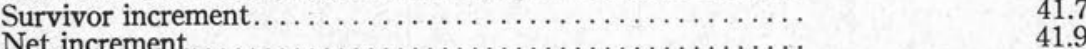

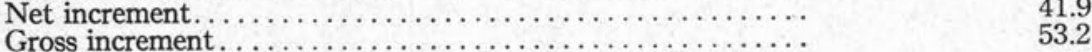

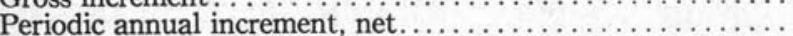

Periodic annual increment, gross. . .

Mean annual increment, actual, at age 125 .

$\begin{array}{ll} & 1.41 \\ & 5.36 \\ & 0.76 \\ & 5.21 \\ & 5.24 \\ 4.19 & 6.65 \\ 5.32 & 5.24 \\ 2.39 & 6.65 \\ & 2.99\end{array}$

(b) Increment excluding ingrowth

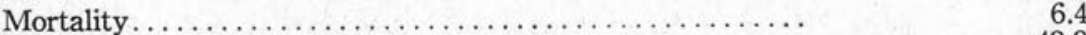

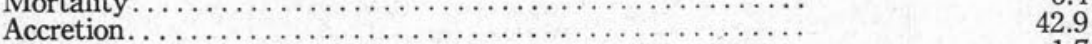

Net increase.................................. 1.7

Survivor increment of original stand................

$\begin{array}{ll}\text { Net increment. . . . } \ldots \ldots \ldots \ldots \ldots \ldots \ldots \ldots \ldots \ldots \ldots \ldots \ldots \ldots \ldots \ldots \ldots \ldots \ldots \ldots & 36.5 \\ \text { Gross increment } & 42.9\end{array}$

Periodic annual increment, net...................... $\quad 3.65$

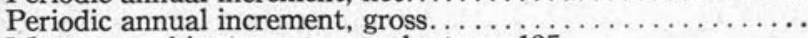

Mean annual increment, actual, at age 125 .

2.36

$\begin{array}{ll} & 0.80 \\ & 5.36 \\ & 0.21 \\ & 4.66 \\ & 4.56 \\ 3.65 & 5.36 \\ 4.29 & 4.56 \\ 2.36 & 5.36 \\ & 2.95\end{array}$

3. The area of the stand is 0.8 hectare.

4. The lowest measured diameter (dbh) class is $20 \mathrm{~cm}(19.6-20.5 \mathrm{~cm})$.

5. Every tree, except ingrowth, grows $2 \mathrm{~cm}$ in a 10 -year period.

6. All ingrowth attains only the first diameter class and remains within the limits of that class until the end of the period.

7. Cutting and dying take place at the same time and in the 10th year, just before the second measurement.

Table 1 illustrates the development of a stand according to these assumptions. There the living trees at the beginning and at the end of the growing period, the ingrowth, and the trees that died or were cut within the growing period are shown in each diameter class by numbers and total cubicmetre volume for the total area. Using these volumes, Table 2 shows the values of calculated increments, and provides a sound comparison and visual representation of them.

\section{Conclusion}

The literature dealing with growth and yield reveals confusion and inconsistency in the terminology employed. The aim of this paper has been to analyze mathematically various terms now current, and to set forth a comprehensive rational set of definitions. If general agreement on them can be reached, then steps might be taken towards their standardization.

\section{References}

Assmann, E. 1970. The principles of forest yield study (Transl. by S.H. Gardiner). Pergamon Press, Oxford. 506 p.

Beers, T.W. 1962. Components of forest growth. J. For. $60(7)$ : 245-248.

Belyea, H.C. 1931. Forest measurement. John Wiley and Sons, Inc., New York, N.Y. 319 p.

Bickford, C.A., F.R. Longwood and R. Bain. 1961. Average growth rates in the spruce-fir region of New England. USDA North. For. Exp. Stn. Paper 140. 20 p.

Bruce, D. and F.X. Schumacher. 1942. Forest mensuration. McGraw-Hill Book Co., Inc., New York, N.Y. 522 p.

Chapman, H.H. and W.H. Meyer. 1949. Forest mensuration. McGraw-Hill Book Co., Inc., New York, N.Y. 425 p.

Davis, K.P. 1966. Forest management: regulation and valuation. McGraw-Hill Book Co., Inc., New York, N.Y. 519 p.

Ford-Robertson, F.C. 1971. Terminology of forest science, technology, practice and products. Soc. Am. For., Washington, D.C. 349 p.

Husch, B., C.I. Miller and T.W. Beers. 1972. Forest mensuration. The Ronald Press Co., New York, N.Y. 410 p.

Loetsch, F., F. Zöhrer and K.E. Haller. 1973. Forest inventory, Volume II (TransI. by K.F. Panzer). BLV Verlagsgesellschaft, München. 469 p.

Marquis, D.A. and T.W. Beers. 1969. A further definition of some forest growth components. J. For. 67(7): 493.

Meyer, H.A. 1953. Forest mensuration. Penns Valley Publishers, Inc., State College, Pa. 357 p.

Meyer, H.A., A.B. Recknagel, D.D. Stevenson and R.A. Bartoo. 1961. Forest management. The Ronald Press Co., New York, N.Y. 282 p.

Prodan, M. 1965. Holzmesslehre. J.D. Sauerländer's Verlag, Frankfurt. 644 p.

Prodan, M. 1968. Forest biometrics (Transl. by S.H. Gardiner). Pergamon Press, Oxford. 447 p.

Robertson, W.M. and G.A. Mulloy. 1946. Sample plot methods. Can. Dep. Mines Resour., Dom. For. Serv. 69 p.

Spurr, S.H. 1952. Forest inventory. The Ronald Press Co., New York, N.Y. 476 p.

\section{Erratum - August issue}

First reference in Day and MacGillivray paper should be Cleary, B.D. "1968", not "1958". 